\title{
大水深海域での湧昇流構造物に作用する潮流力と波力について

\author{
Fluid Forces Exerted by Tidal Currents and Waves on \\ Submerged Upwelling Structures in the Deep Sea
}

\author{
木田英之 ${ }^{1} \cdot$ 井内国光 $^{2} \cdot$ 中村孝幸 $^{2} \cdot$ 出口一郎 ${ }^{3} \cdot$ 古木 宏 $^{4} \cdot$ 境 $^{\text {大輔 }}{ }^{4}$ \\ Hideyuki KIDA, Kunimitsu INOUCHI, Takayuki NAKAMURA, Ichiro DEGUCHI \\ Hiroshi KOGI and Daisuke SAKAI
}

\begin{abstract}
This study mainly deals with characteristics of hydrodynamic forces on upwelling structures constructed on the sea floor with comparatively deep depth, say about $200 \mathrm{~m}$. Two different configurations of upwelling structures, typically a vertical plate model and a V-shaped plate model in the horizontal plane, were used as a practical model. The numerical analysis based upon CFD was applied to examine the effectiveness of upwelling structures and fluid forces in a quasisteady flow such as a tidal current. Experimental verifications for such a numerical study were also carried out. The importance of wave actions on the upwelling structure was further examined theoretically for the stability analysis and structural design.
\end{abstract}

\section{1.はじめに}

近年，水深 $200 \mathrm{~m}$ 程度の大陸棚を対象にして，底設構 造物の設置により海底付近の栄養塩類を有光層まで湧昇 させ, 海域の基礎生産力を増強しょうとする試みが進め られつつある（例えば橋本・浜崎, 2007)。水産庁で推 し進められているフロンティア漁場整備事業は, 日本近 海での漁場の開発を目的に，経済的かつ確実な湧昇流の 発生が期待できる新規構造体が必要とされている。この ような構造物は, 人工海底山脈と称され, 大陸棚（水深 200m）海域での深層水を海面付近まで湧昇させることを 目標としている.

既に著者ら（木田ら，2008，2009）は, 大水深海域で も経済的な建設が可能になると考えられる, 直立壁構造 の湧昇流構造体を対象にして, 湧昇流の生成効果が得ら れる構造形状を数值流体力学に基づく解析法と水理模型 実験により検討してきた。その結果，平面形状が V字型 構造の堤体は, I字型やX字型の平面形状のそれより湧昇 流の生成効果に優れることなどを明らかにした。このよ うな V字型堤体の優位性は, 浅枝ら（1990）や池田ら (1992) によっても指摘されている.

本研究では, 比較的高い湧昇効果が認められた, V字 型の平面形状を有する湧昇流構造体を中心にして, 潮流 などの準定常流による流体力の特性を 3 次元流れの数值 シミュレーションおよび定常流を用いた水理模型実験に より明らかにする。この際，流体力係数に及ぼす模型の

$\begin{array}{llll}1 & \text { 正会員 } & \text { 工修 } & \text { 日鉄トピーブリッジ(株) } \\ 2 & \text { 正会 } & \text { 工博 } & \text { 愛媛大学大学院准教授理工学研究科 } \\ 3 & \text { 正会 } & \text { 工博 } & \text { 大阪大学大学院教授工学研究科 } \\ 4 & \text { 学生会員 } & & \text { 大阪大学大学院工学研究科 }\end{array}$

縮尺効果などについても考察する，一方，現場海域では， 潮流のみならず波の作用も受けることから, 作用波力の 特性を理論的に検討すると共に潮流力との比較から想定 すべき設計外力について考察する.

\section{2. 数值解析法と湧昇効果に関する従来の成果 (木田ら, 2009) の概要}

\section{（1）数值解析法}

流れ場の数值シミュレーションは, DHIで開発された 3 次元非定常流体解析モデルである MIKE3（DHI, 2005） を用いた。今回の解析では, 静水圧近似は使用せず, Boussinesq近似を用いた。 また乱流モデルは, $\mathrm{k}-\varepsilon$ 型 2 方程式モデルを用い, その場合の数值定数は一般的に推 奨されている值を準用した.このモデルでは塩分や水温 による流体密度の空間変化も考慮できるが, 今回は密度 を一定としたときの結果のみを示す.

数值解析のための離散法には，空間，時間共に差分法 を採用し, 解析領域の水平方向のメッシュ分割 $(\Delta \mathrm{x}, \Delta \mathrm{y})$ は, 図-1に示すように4層の Nested Hydro-Dynamic

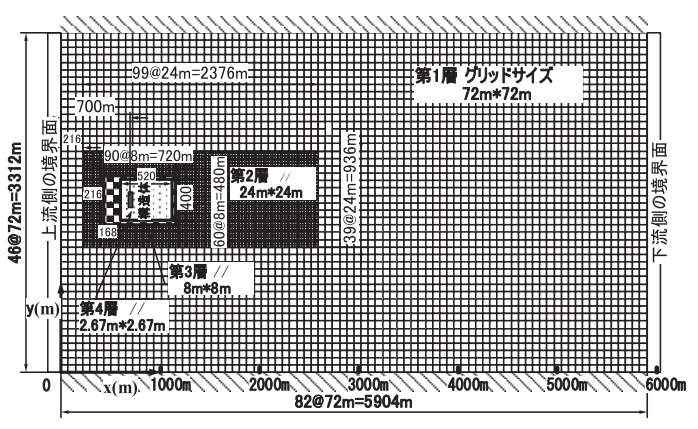

図-1 解析領域の水平面内におけるメッシュ分割 


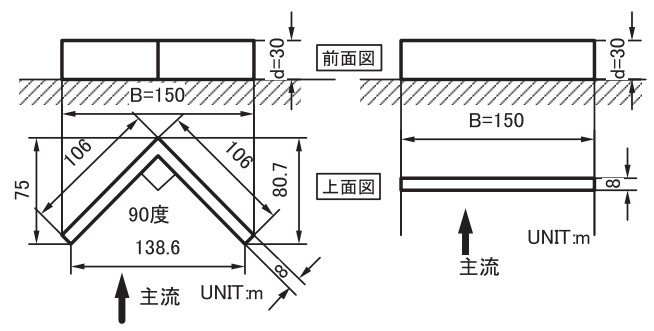

(a) V字型構造物

(b)I字型構造物

moduleを用いた。具体的には, 構造体のまわりで最も小 さな $\Delta \mathrm{x}=\Delta \mathrm{y}=2.67 \mathrm{~m}$ を用い, 遠ざかると粗くして, 順次, $8 \mathrm{~m}, 24 \mathrm{~m}, 72 \mathrm{~m}$ とした。この際, 鉛直方向のメッシュ分 割 $(\Delta \mathrm{z})$ は, 共通して $4 \mathrm{~m}$ と一定にした。また, 時間ス

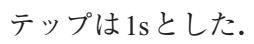

解析領域は長さ $5,904 \mathrm{~m}$, 幅 $3,312 \mathrm{~m}$, 水深 $200 \mathrm{~m}$ の水路 であり, 水路の中央部, $\mathrm{x}=750 \mathrm{~m}, \mathrm{y}=1,700 \mathrm{~m}$ 中心とす る位置に図-2に示す2種類の構造体をそれぞれ設置した 場合の流況について数值害験を行った。湧昇効果に及ぼ す構造体の寸法を検討するため, 高さ $\mathrm{d}$ と左右幅 $\mathrm{B}$ 各 種に変化させているが, 以下の流体力の検討では図-2に 示す諸元の構造体を基準にして, 主に左右幅を増減した ときの影響を紹介する.

流れ場の境界条件については構造体の左側境界が流入 口であり，ここでは流速を設定した．右側境界の流出口 では水位を設定して, 計算期間中にわたり一定水位とな るようにした。海底ではノンスリップ条件を設定し, 海 底摩擦を考慮して粗度長を $0.05 \mathrm{~m}$ とした。側面はスリッ プ条件, 上面は自由水面とした。

流入口での主流速は, 現地の観測デー夕を参照して, 主に $0.3 \mathrm{~m} / \mathrm{s}$ としたが, 安定性の検討も行えるように, よ り大きな $0.7 \mathrm{~m} / \mathrm{s}$ についても対象とした。初期条件は, す べての解析領域で流速 0 の静止流体としているが, 流入 口で流速を急に上げるとショック波が発生する.このこ とを避けるため, 20分間はウォームアップ時間とし, 線 形的に主流速まで増加させるようにした。

\section{(2) 数值シミュレーションによる湧昇効果の概要}

初期状態に扔いて底面から厚さ $12 \mathrm{~m}$ の領域に無次元濃 度 1 の物質を敷き詰め, また左右の境界でも同様の濃度 值を解析時間中与え, これをトレーサー物質として可視 化することで湧昇流の発生の状況を考察した。このとき トレーサー物質の移動は移流項のみを考慮して, 渦度拡 散係数は 0 とした.

図-3および図-4にI字型およびV字型堤体の3 時間経過 後の低層トレーサ物質の濃度分布を示す。このとき, 構 造体などの諸元は図-2に示すもので, 主流速は $0.3 \mathrm{~m} / \mathrm{s}$ と してある.トレーサ物質は海底上 $12 \mathrm{~m} て ゙$ 濃度が1から0に

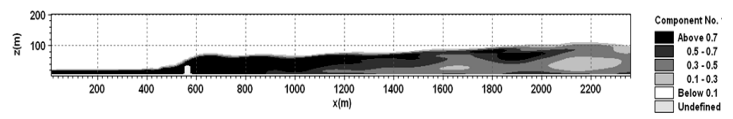

図-3 底層トレーサの湧昇状況; I字型堤体 $(U=0.3 \mathrm{~m} / \mathrm{s})$

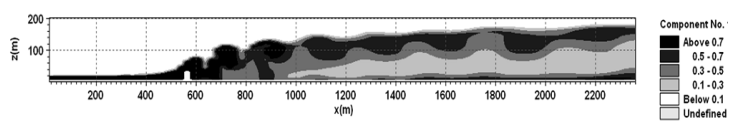

図-4 底層トレーサの湧昇状況; $\mathrm{V}$ 字型堤体 $(U=0.3 \mathrm{~m} / \mathrm{s})$

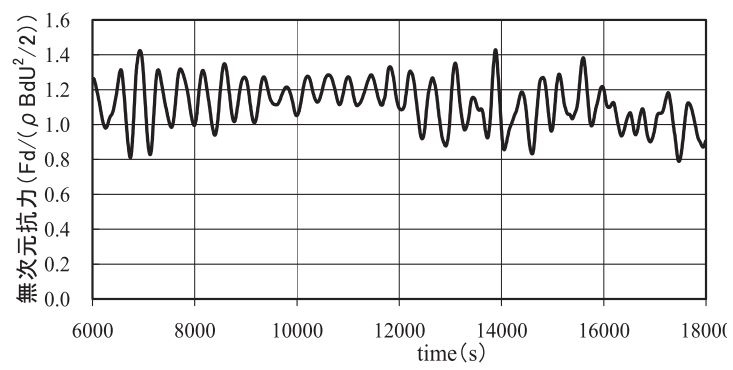

図-5 V字型堤体に作用する抗力（U=0.7m/s, B=150m, d=30m）

階段状に変化するよう与えているので, その分布の変化 から巻き上がりの状態をみることができる，これらの図 はx軸に平行な $\mathrm{x}-\mathrm{z}$ 軸断面 $(\mathrm{y}=1716 \mathrm{~m})$ で切った鉛直断面 図で示している.

両図の比較から, V字型の巻き上げ性能は優秀である ことや, 周期的な濃度変動が顕著に現れることなどが確 認できる．さらに堤体より下流側へ6B（=900m）の位置 を検查面として, そこでの等濃度線 $\mathrm{c}=0.1$ の海底面から の高さを巻き上げ高さ $\mathrm{hv}$ と定義すると, I字型およびV 字型の hv はそれぞれ $95 \mathrm{~m}$ と $167 \mathrm{~m}$ でV 字型は 1.7 倍の上昇 高さを示すことなどが判明している. そして，このよう にV字型堤体が湧昇効果に優れることは実験的にも確認 されており, その詳細については, 前報告（木田ら, 2009）を参照していただきたい.

\section{3. 作用流体力}

\section{（1）流体力係数}

図-5は, 上記の数值シミュレーション結果に基づき求 めた $\mathrm{V}$ 字型堤体への抗力の算定結果の代表例を示す. 図 中には, 湧昇流れの定常状態が現れる100分以降の結果 について示す. 図中で抗力 $\mathrm{Fd}$ は, 動圧 $\rho U^{2} / 2$ と堤体の流 れ方向への射影面積Bdの積で除した無次元抗力で表示し てある. 抗力は, $400 \mathrm{~s}$ 程度の比較的長い周期の時間変動 を示す傾向にあり，これはV字型堤体を過ぎる流れにお いて図-4に見られるように渦列が形成されることによる ものと考えられる。

図-6は, 図-5に示すような抗力の時系列波形から，時 間平均を求め, 平均抗力係数 $\mathrm{Cd}$ を $\mathrm{I}$ 字型扮よび $\mathrm{V}$ 字型堤 体の両者について示す. 横軸には, 構造体の横幅と高さ 


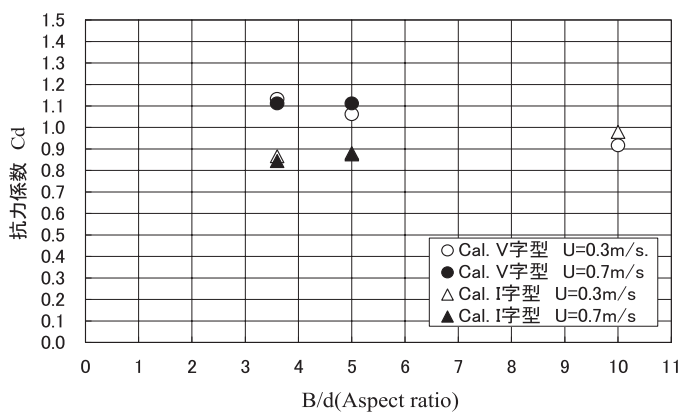

図-6 V字型およびI字型堤体の横幅 ・高さ比による抗力係数 $\mathrm{Cd}$ の変化 $(\mathrm{B}=108 \sim 300 \mathrm{~m}, \mathrm{~d}=30 \mathrm{~m})$

の比である B/d（aspect ratio）を示す.

この図より, B/dが4〜 5 程度ではV 字型堤体の抗力係 数がI字型堤体のそれより大きくなることや，さらに扁 平な構造体になると, 両堤体で抗力係数に差異が見られ なくなることなどが分かる.また, 抗力係数に及ぼす主 流速の影響は， $0.7 \mathrm{~m} / \mathrm{s}$ までと比較的遅い流速に対しては ほとんど見られない。風荷重を想定した設計指針（土木 学会編, 1973）によると, I字型堤体と類似した一辺を地 に接した平板の抗力係数の推奨值は 1.2 である. ただし, $\mathrm{B} / \mathrm{d}$ による補正係数も提示されており, $\mathrm{B} / \mathrm{d}$ が 8 以下では 補正係数 $0.6 \sim 0.7$ を乗じることとされている. すなわち, 上記の $\mathrm{I}$ 字型堤体の $\mathrm{Cd}$ は $0.7 \sim 0.85$ 程度が推奨值となり, 風荷重を想定した結果と数值シミュレーションに基づく 算定結果とはほぼ一致することが分かる，なお，今回の 算定でのレイノルズ数は, 堤体高さ $\mathrm{d}$ を代表長に採ると, ほぼ $10^{7} \sim 2 \times 10^{7}$ の範囲にあり，いわゆる限界レイノル ズ数を超えた流れと推定される.

\section{(2) 流体力の分布}

図-7，8は，それぞれI字型およびV字型堤体の没水表 面で，上下流の表裏の関係位置での動圧の差 $\Delta \mathrm{p}$ の空間分 布をコンター図にて示す。すなわち，このコンター図を 参照することで，構造体に作用する局部流体力の分布を

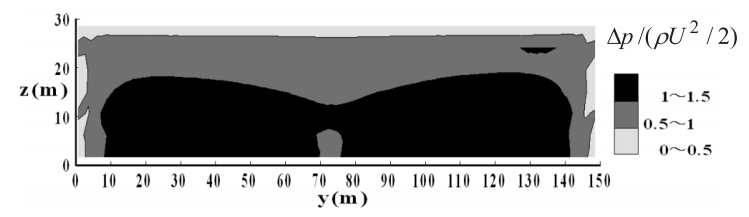

図-7 I 字型堤体の前後壁の圧力差（差圧 $\Delta \mathrm{p} ）$ のコンター図 (速度水頭分の動圧で無次元化, $\mathrm{B} / \mathrm{d}=5, \mathrm{U}=0.7 \mathrm{~m} / \mathrm{s}$ )

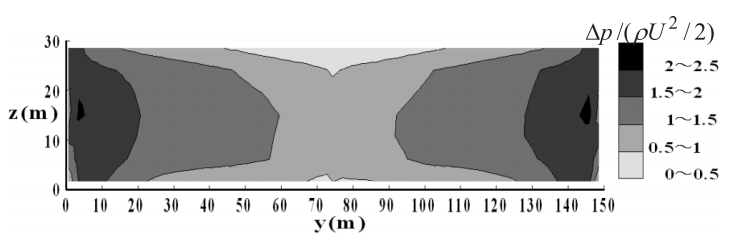

図-8 V 字型堤体の前後壁の圧力差（差圧 $\Delta \mathrm{p} ）$ のコンター図 (速度水頭分の動圧で無次元化, $\mathrm{B} / \mathrm{d}=5, \mathrm{U}=0.7 \mathrm{~m} / \mathrm{s}$ )
知ることができる.

これらの図から，I字型堤体では，堤体下部に潜り込 む馬蹄形渦のような流れが現れるためか, 前後壁の圧力 差は構造体の下半分で大きく, 上半分と左右端では小さ くなる傾向にある。一方，V字型堤体の前後壁の圧力差 は，流速が大きくなるV字の収束部で低く，両翼に広が るほど高くなるなど，構造体による差異が見られる，そ して, このような差異は, V字型堤体が I字型堤体より湧 昇流が生起しやすいことと密接に関係しているものと推 測される.

\section{4. 実験装置および実験方法}

\section{（1）実験水槽}

実験に用いた水槽は、図-9に示す上流端に整流板を設 けた幅 $1.5 \mathrm{~m}$ 、深さ $1.1 \mathrm{~m}$ 、長さ $22.7 \mathrm{~m}$ の 2 次元循環式開 水路である。この水路は, 長手方向の両端部を除き, 鋼 製板により上下に分離されて抢り，上部水路の両端部付 近に設置されたプロペラモータ2機を駆動することで, 一方向流が発生できるようにしてある。このプロペラモ ータはプロペラの回転数を無段階で調整でき、最大 $0.6 \mathrm{~m}$ /s の流速を発生させることができる。構造物は上部水路 でそのほぼ中央部に設置した。このとき主流速は, 電磁 流速計を模型堤体の上流側ほぼ $1 \mathrm{~m}$ の位置と模型の真上で その上端と水面との中間点の 2 力所に設置して計測した.

\section{（2）模型堤体および面圧計の配置}

模型堤体には, やはり $\mathrm{I}$ 字型およびV字型堤体の2種類 を用いた。図-10は，代表例としてV字型堤体の模型の水 路への設置状況とその片側の構成板に取り付けた面圧計 の配置状況を示す. 想定した模型の縮尺は, 1/333である. 面圧計には，三計エンジニアリング社製の直径 $10 \mathrm{~mm}$ の 超小型圧力センサーを計20台用いて, 構成板の裏表で一 対となるように設置して局部的な流体力の分布が測定で きるようにした。

また，I字型堤体の模型についても，同様に計 20 台の 面圧計を設置した。そして，模型堤体に作用する流体力

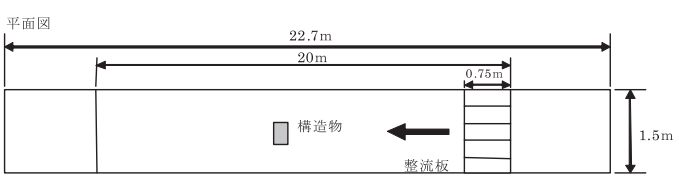

(a) 上面四

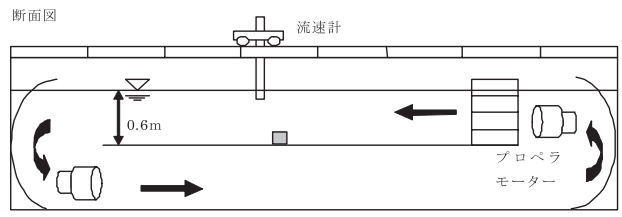

(b) 側面図

図-9 実験に用いた上下回流式の開水路 


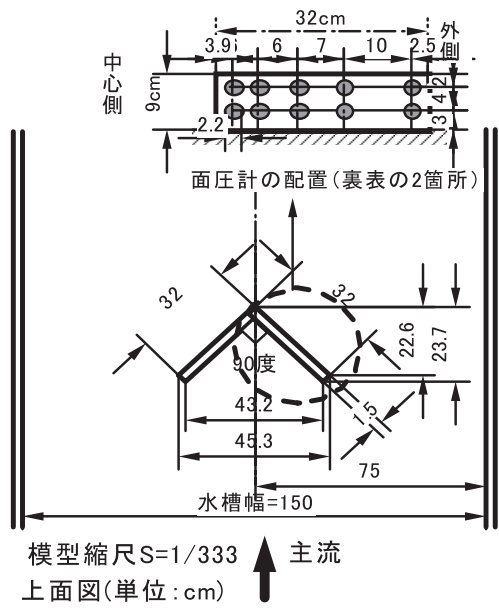

図-10 V字型模型と面圧計の配置 $(\mathrm{B} / \mathrm{d}=5)$

表-1 実験条件と現地換算量

\begin{tabular}{c|c|c|c}
\hline \multicolumn{2}{c|}{ 模型 (水深60 $\mathrm{cm})$} & \multicolumn{2}{c}{ 現地換算量 $($ 水深 $200 \mathrm{~m})$} \\
\hline $\mathrm{U}(\mathrm{cm} / \mathrm{s})$ & Re数 & $\mathrm{U}(\mathrm{m} / \mathrm{s})$ & Re数 \\
\hline 13.1 & $9.10 \mathrm{E}+03$ & 2.4 & $5.54 \mathrm{E}+07$ \\
\hline 16.3 & $1.13 \mathrm{E}+04$ & 3.0 & $6.86 \mathrm{E}+07$ \\
\hline 20.8 & $1.44 \mathrm{E}+04$ & 3.8 & $8.75 \mathrm{E}+07$ \\
\hline 25.1 & $1.74 \mathrm{E}+04$ & 4.6 & $1.06 \mathrm{E}+08$ \\
\hline 28.4 & $1.97 \mathrm{E}+04$ & 5.2 & $1.20 \mathrm{E}+08$ \\
\hline
\end{tabular}

は, 構成板の裏表の差圧を求めた後に, 面圧計が代表す る面積を乗じて加算することで近似的に求めた.

\section{（3）実験条件}

実験で用いた水理条件は, 原則的に現地量をフルード の相似則により模型化した条件とした。ただし，予備実 験の段階で, 上記した現地を想定した数值シミュレーシ ヨンに用いた流速（例えば現地で $0.7 \mathrm{~m} / \mathrm{s}$ ）を想定した模 型実験では, 水流による動圧の変化が圧力センサーの測 定精度を下回り，正確な測定が難しいことが判明した。 このため, 模型の主流速としては, 表-1に示すように, 現地量を大幅に上回る值を用いて，抗力係数の同定とい う観点から検討を進めた. 表中には, 想定した流速条件 下でのレイノルズ数 (Re 数;堤体高さ $\mathrm{d}$ が代表長) につい ても併せ示してあるが, 現地量は模型量の 6000 倍程度と 非常に大きな相違があることに注意する必要がある.

\section{5. 潮流力の実験結果}

図-11 は，I字型挹よび V字型の模型堤体の抗力係数 $\mathrm{Cd}$ をRe数の変化で示す．この図から，先に示した図-6の算 定結果と同様に, $\mathrm{V}$ 字型堤体の $\mathrm{Cd}$ がI字型のそれよりも 大きくなることが分かる. ただし, 両模型のCdは, 現地 を想定した場合に比較して， $0.2 \sim 0.3$ 程度増加すること が認められる．この理由としては，やはり模型と原型の
レイノルズ数の相違による流況の相違が挙げられ, 特に 構造体の背後域での剥離流れの挙動の相違によるものと 推定される.

このことを検証するため, 本研究では, 模型スケール のV字型堤体を対象にして, 数值シミュレーションを実 施してみた。この算定では, 上記の2.で紹介した数值算 定の諸条件を長さのスケールで $1 / 333$ に縮尺したものを 概略的に使用して, 離散化条件などは同一に保持した。 例えば，構造体の寸法は，1/333に縮小してあるが, 没水 表面を表すメッシュ数は前出の現地想定の場合と同じに してある.

この数值シミュレーションに基づくV字型模型堤体の 抗力係数の算定結果を図-11 中に併せ示す．このときの 算定結果と実験結果との対応は良好であり, 現地を想定 した算定結果との相違はやはり模型と原型のレイノルズ 数の相違によるものと判定される. 今後, 模型と原型の 構造体まわりの流れの相違の検討など, さらに詳細な検 討を進めていきたい.

図-12 は，図-8の実験結果に対応するもので，V字型堤 体の右翼に沿って裏表に配置した面圧計による差圧の分 布の実験結果を示す，差圧 $\Delta \mathrm{p} は ，$ 速度水頭に対応する動 圧で無次元化してある。この図から, 差圧 $\Delta \mathrm{p} は$, 図-8の 算定結果と同様に, $\mathrm{V}$ 字の中心から外側に向かって増加 する傾向にあり, 両者の傾向はほぼ一致することが確認 できる.

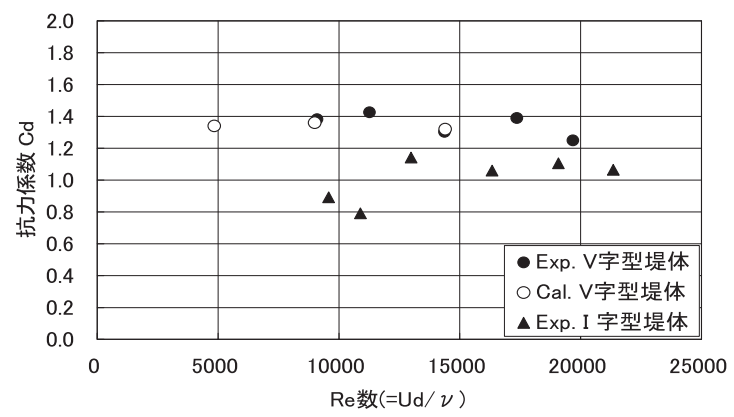

図-11 各堤体の抗力係数 $(\mathrm{B} / \mathrm{d}=5)$

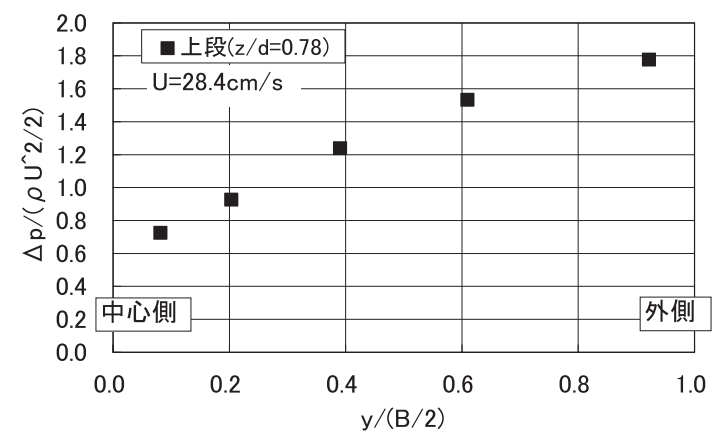

図-12 V字型堤体の右翼に沿う前後壁の圧力差の分布 $(\mathrm{U}=28.4 \mathrm{~cm} / \mathrm{s}, \mathrm{B} / \mathrm{d}=5$, 上段側 $)$ 


\section{6. 作用波力の推定と潮流力との関係}

湧昇流構造物は，大波浪の作用を受けやすい外海域に 設置されるのが一般であり，ここでは，V字型と $\mathrm{I}$ 字型堤 体を対象にして，3次元グリーン関数法（Garrison, 1978） による波力の算定を各種の設置水深の条件を採用して行 ってみた。

図-13 は，設置水深 $200 \mathrm{~m}$ の時の水平波力の算定結果を 無次元波力強度で示す，構造体は，図-2に示すものであ る.この図から，長周期の条件になると波力強度が増大 することや，波力の空間的な位相差がほとんどないI字 型堤体で波力強度が大きくなることが分かる.

図-14 は，湧昇効果に優れるV 字型堤体の水平波力を各

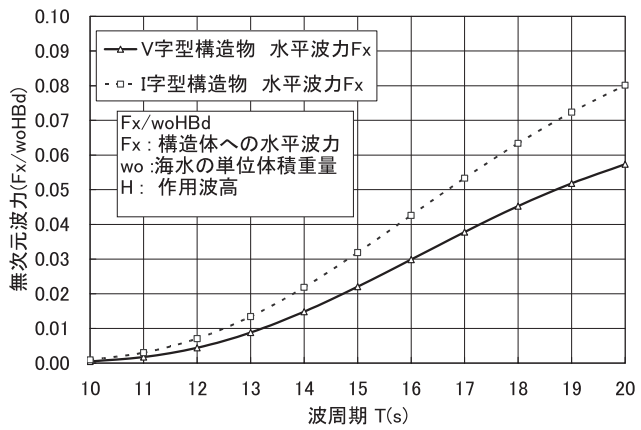

図-13 各堤体の水平波力強度 $(B / d=5, d=30 m, h=200 m$, 直角 入射）

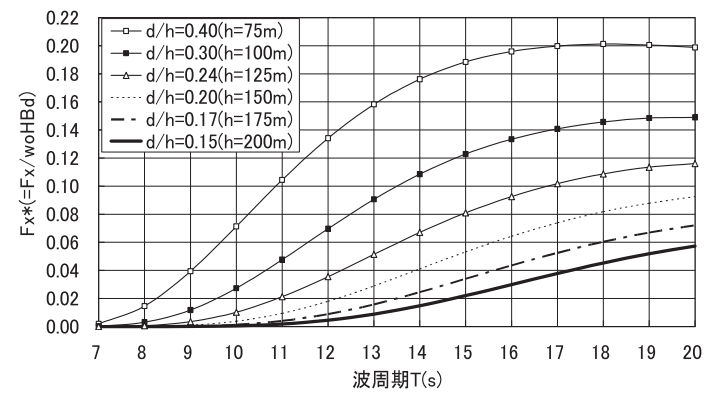

図-14 V 字型堤体に作用する水平波力 $\mathrm{Fx}$ の設置水深と波周期 による変化 $(\mathrm{d}=30 \mathrm{~m}, \mathrm{~B}=150 \mathrm{~m}$, 直角入射 $)$

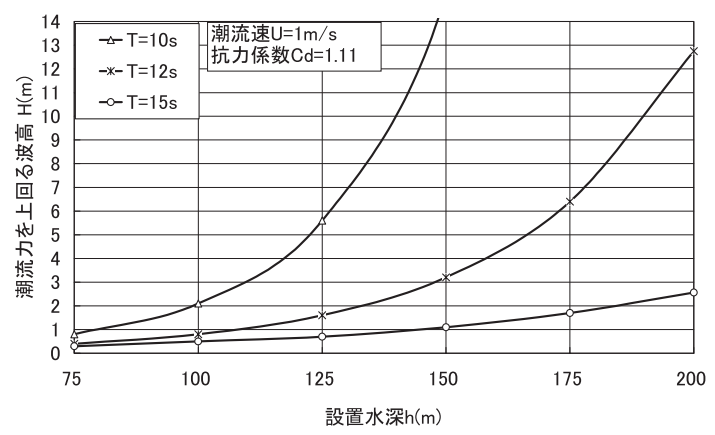

図-15 各設置水深で水平波力が潮流力を上回る波高条件 ( $\mathrm{d}=30 \mathrm{~m}, \mathrm{~B}=150 \mathrm{~m}, \mathrm{U}=1 \mathrm{~m} / \mathrm{s}, \mathrm{Cd}=1.11)$
設置水深および波周期の条件に対して示す。この図より， 作用波の周期 Tが 10s〜20sのうねり性の波に対しては, 設置水深 $\mathrm{h}$ が $150 \mathrm{~m}$ より浅くなると，水平波力は急激に増 加する傾向にあることが分かる.

図-15 は，各設置水深において水平波力が潮流力を上 回るための波高值をうねり性の波周期（T=10,12,15s）に 対して示す。このとき，想定した潮流速は $U=1 \mathrm{~m} / \mathrm{s}$ であ る.また，抗力係数は，図-6の結果を参照して $\mathrm{Cd}=1.11$ と仮定した。この図より， $\mathrm{T}=15 \mathrm{~s}$ の条件では，設置水深 が $200 \mathrm{~m}$ 程度と比較的深くても，潮流力を上回る限界波 高は $2.5 \mathrm{~m}$ 程度とかなり低く, 設計外力として波力も重要 になることが確認できる.

\section{7. 結語}

（1）現地を想定した V 字型堤体の抗力係数 $\mathrm{Cd}$ の算定值は 1.1 程度であり，I字型堤体のそれより大きくなる.

（2）模型スケールでのV字型堤体の $\mathrm{Cd}$ の算定值は，縮尺 効果によるものか原型のそれよりも2 割程度大きくな ることや実験による $\mathrm{Cd}$ の測定值とほぼ一致する.

（3） V字型と I字型の湧昇流構造体に作用する波力は，長 周期の条件になるほど波力強度が増大することや，波 力の空間的な位相差が少ない $\mathrm{I}$ 字型堤体で波力強度が 大きくなる.

（4）湧昇流構造体に作用する波力は，設置水深が $200 \mathrm{~m}$ 程度と比較的深い場合でも，うねり性の波が作用する 海域では，潮流力を上回る波力が作用する可能性が高 く, 安定性を検討する際に注意する必要がある。

\section{参 考 文 献}

浅枝 隆・中井正則・玉井信行 - 堀川清司 (1990)：V字形 構造物による上昇流，土木学会論文集，423/II-14号， pp. $83-90$.

池田駿介・武若 聡・二瓶泰雄・秋山信義（1992）：各種構 造物による湧昇流の発生に関する実験的研究, 海岸工学 論文集, 39巻, pp.896-900.

木田英之・井内国光・中村孝幸（2008）：3 次元数值シミュ レーションに基づく大水深海域での湧昇流生成構造物の 開発，海洋開発論文集，24巻，pp.399-404.

木田英之 ·井内国光 - 中村孝幸 - 出口一郎 （2009）：大水深 海域での直立壁構造物による湧昇流, 海洋開発論文集, 25 巻, pp.1377-1382.

土木学会編（1973）：海洋鋼構造物設計指針（案）解説，pp. 16-19.

橋本 牧・浜崎宏正（2007）: 沖合大水深海域を対象とした 漁場整備の推進について, 海洋開発論文集, 第 23 巻, pp.1-5.

DHI(2005): MIKE 3, Coastal Hydraulics and Oceanography Hydrodynamic Module Scientific Documentation, Danish Hydraulic Institute (DHI).

Garrison, C. J.(1978): Hydrodynamic loading of large offshore structures - Three dimensional source distribution methods. In Numerical Methods in Offshore Engineering, John Wiley, pp. $97-140$ 